\title{
Forty Years of Estudios de Economía
}

Rómulo A. Chumacero*

Forty years ago, the Department of Economics of the University of Chile launched the first issue of Estudios de Economía. In its beginnings, the journal mainly published empirical papers focused on the Chilean economy. Now, it has naturally progressed to become a general purpose journal that intends to publish theoretical and empirical papers on the frontier of the discipline.

After forty years and more than five hundred papers published, Estudios de Economía has established itself as a truly international journal. Presently, approximately $35 \%$ of the papers submitted for publication to the journal come from academics of European universities or institutions, 20\% come from academics of Chilean universities, 30\% from academics of other countries in North, Central, and South America, and the remaining 15\% from the rest of World.

Estudios de Economía was an early user of the internet as a means to divulge the papers published. In fact, all papers published in the journal are available in electronic format on its web page (http://estudiosdeeconomia.cl/). Estudios de Economía is also available in most of the relevant academic databases of the field (including Scielo, EBSCO, RePEc, Scopus, etc). Furthermore, the journal was the first Chilean based journal of the field to achieve ISI status.

Estudios de Economía will continue to look for effective and innovative ways to divulge the academic research it publishes. We know that the success of the journal depends on the quality of its papers. Thus, we thank all the anonymous referees for their timely and rigorous evaluations, to the contributors that have favored us in the past, and invite all academics to contribute to the success of Estudios de Economía in the future.

Forty uninterrupted years of publishing Estudios de Economía also require the dedicated effort of secretaries, executive editors, proof-readers, and editors. Next, follows the list of editors that have contributed with their dedication and that have made what Estudios de Economía is today.

James Locke (1973)

Gunther Held (1974-1981)

Hugo Trivelli (1975-1977)

Mario Reyes (1978-1979)

Alfonso Morandes (1980-1981)

Cristián Morán (1981-1982)

Tarcisio Castañeda (1982-1984)

Hernán Cheyre (1983-1984)

Francisco Labbé (1983-1984)
Pedro Jeftanovic (1974-1979)

Roberto Zahler (1974-1975)

Jorge Marshall S. (1978-1982) (1992-1994)

Vittorio Corbo (1980)

Sergio Melnick (1981-1984)

Marcelo Figerola (1981-1982)

Luis Riveros (1983-1985) (1995-1996)

Erik Haindl (1983-1985)

Lucía Pardo (1983-1984)

* Department of Economics. University of Chile. E-mail: rchumace@econ.uchile.cl 
$\begin{array}{ll}\text { Alvaro Saieh (1983-1984) } & \text { Clemente Torres (1984-1986) } \\ \text { Joaquín Vial (1984-1985) } & \text { Hermann von Gersdorff (1986) } \\ \text { Ricardo Zabal (1986-1991) } & \text { Rodrigo Fuentes (1992-1998) } \\ \text { Jaime Vatter (1992-1996) } & \text { Ricardo Paredes (1995-1996) } \\ \text { José Miguel Sánchez (1997-2003) } & \text { José Miguel Benavente (2003-2007) }\end{array}$

We strive to continue to make Estudios de Economía the primer journal that our readers deserve.

Sincerely,

Rómulo A. Chumacero

Editor

1999-Present 